\title{
Pemberton v Inwood
}

Court of Appeal: Gloster, Underhill and Asplin LJJ, 22 March 2018 [2018] EWCA Civ 564

Anglican clergy - same-sex marriage - withdrawal of licence - direct discrimination and harassment

Following the enactment of the Marriage (Same Sex Couples) Act 2013, the Revd Canon Jeremy Pemberton married his partner, Laurence Cunnington. As a result, the Rt Revd Richard Inwood, at the time Acting Bishop of Southwell and Nottingham, revoked his permission to officiate (PTO) within the diocese and declined to grant him the extra parochial ministry licence (EPML) that was a necessary requirement for him to take up the post of Chaplaincy and Bereavement Manager at the Kingsmill Hospital run by the Sherwood Hospitals NHS Trust. As a result, the Trust withdrew its offer of the post. Canon Pemberton took the matter to an Employment Tribunal (ET), claiming direct discrimination pursuant to sections 13 and 53 of the Equality Act 2010 and harassment pursuant to sections 26 and 53 of that Act in relation to the revocation of the PTO and the refusal to grant him an EPML. He was unsuccessful both at the original tribunal and on appeal to an Employment Appeal Tribunal (EAT).

His further appeal to the Court of Appeal was dismissed. The court concluded that there had been no error of law in the reasoning of the EAT. Although the EPML was a condition of employment with the Trust, it was clear from the job description that, although there were some duties which were of a general nature, the Trust intended to employ a properly accredited minister of religion to carry out all aspects of the post, including conducting Church of England services if required. It required a clergyman properly licensed and approved by his bishop to carry them out. Inevitably, the principal purpose of the Trust was to provide medical services. However, in the circumstances, that did not prevent the EPML for the purposes of employment with the Trust being for the purposes of organised religion. It was intended to employ the canon specifically because of his status as a minister of religion and in part to conduct religious services. In this case, the employment itself was in part for the purposes of an organised religion.

The EAT had been correct to conclude that 'doctrines' for the purposes of paragraph 2(5) of Schedule 9 had to be read more widely than what a particular church or religious organisation considered to be doctrine in the strict sense; paragraph 2(5) uses the term 'doctrines' and not 'doctrine' and is intended to apply in relation to all religions. It should be construed to mean the teachings and beliefs of the particular religious organisation, which may be wider than what it itself labels doctrine. Moreover, even if that were not the case, Canon A 5 itself referred to the doctrine of the Church of England in wide terms and stated merely that such doctrine was to be found in particular in the specific documents referred to. Accordingly, the EAT had been correct to conclude 
that the ET was entitled to find that the doctrines of the Church were as stated in Canon B 30, with specific regard in relation to same-sex marriages to the statement of Pastoral Guidance from the House of Bishops. It was not necessary that there should be an express provision prohibiting a priest from entering into a same-sex marriage and spelling out the consequences if he or she did so. The teaching and doctrine of the Church was clearly spelt out in Canon B 30, paragraph 1 of which made it plain that marriage was regarded as being between one man and one woman and delimited the concept so as to exclude same-sex marriage. Furthermore, it was made clear in paragraph 3 that a priest was expected to uphold what was described expressly as the Church's doctrine of marriage. Although the Marriage (Same Sex Couples) Act 2013 had extended the meaning of marriage, the position of the Church of England had been carefully preserved in sections 1(3), 1(4) and 11. The EAT had not, therefore, erred in law in deciding that the ET had been entitled to find that the requirement had been applied so as to comply with the doctrines as found.

As to the claim of harassment, the court dismissed the appeal on that ground also. However profoundly upsetting Canon Pemberton had found the Church's official stance on same-sex marriage and its impact on him, it did not follow that it was reasonable for him to regard his dignity as violated or that he had been placed in an intimidating, hostile, degrading, humiliating or offensive environment by the Church applying its own sincerely held beliefs in a way expressly permitted by Schedule 9 to the Equality Act. If a person belongs to an institution with known, and lawful, rules, it implies no violation of dignity, and is not cause for reasonable offence, that those rules should be applied to that person, however wrong he or she may believe them to be. Not all opposition of interests is hostile or offensive. It would be different if the bishop had acted in some way which impacted on Canon Pemberton's dignity, or created an adverse environment for him, beyond what was involved in communicating his decisions; but that was found by the ET not to be the case. [Frank Cranmer]

doi:10.1017/So956618X18000856

\author{
Re All Saints, Buncton \\ Chichester Consistory Court: Hill Ch, 11 April 2018 \\ [2018] ECC Chi 1 \\ Confirmatory faculty - architect's misconduct - removal from diocesan list - \\ costs
}

Works of redecoration by a single coat of limewash were undertaken to the nave of this Grade I listed Norman church in 2013. The Diocesan Advisory Committee (DAC) had issued a notification of advice recommending that the proposed 